\title{
Internet resources for distance education
}

\author{
By Rob Morrison and Jill H. Ellsworth
}

\section{A selected list}

$\mathbf{T}$ he Internet is full of resources for those interested in distance education (DE). As with all subjects, information can be obtained using Internet search tools such as gopher, Veronica, Jughead, and WAIS. Using distance education/learning and adult education/learning, these searches reveal many interesting documents, sites, and databases.

J. H. Ellsworth maintains a list called "Dr. E's Eclectic Compendium of Electronic Resources for Adult/Distance Education." This resource is available as part of the University of Michigan's Clearinghouse for Subject-Oriented Internet Resources Guides. Current access is through anonymous ftp and gopher. (Ftp host: una.hh.lib.umich.edu, path: /inetdirs, file: disted: ellsworth).

For the purpose of this article, DE is defined as any education taking place at a distance where a geographical separation exists between the instructor and the learner.

\section{Scholarly discussion lists}

There are several scholarly discussion lists explicitly focussed on DE, as well as a number of more general lists which touch on DE regularly.

- OFFCAMP. Established by Wayne State University to provide a forum to discuss issues on library services to remote users. Subscribe: LISTSERV@WAYNEST1.BITNET.

- DEOS-L. The Distance Education Online Symposium List. Sponsored by the American Center for the Study of Distance Education
(ACSDE) at Pennsylvania State University. This forum promotes discussion of $\mathrm{DE}$ issues worldwide. The center also produces a newsletter called DEOSNEWS. Subscribe: send the message: SUB DEOS-L Your Full Name to LISTSERV@PSUVM.BITNET or LISTSERV@ PSUVM.PSU.EDU.

- DEOSNEWS. The Distance Education Online Symposium News. Produced by the American Center for the Study of Distance Education. An international electronic journal. Subscribe: send the message: SUB DEOSNEWS Your Full Nam? to LISTSERV@PSUVM.BITNET or LISTSERV@PSUVM.PSU.EDU.

- ADLTED-L. The Canadian Adult Education Network provides a forum for discussions worldwide. Subscribe: LISTSERV@UREGINA1. bitnet.

- EDISTA. Operated by the University Distance Program (UNIDIS) at the University of Santiago in Chile. Subscribe: send the message: SUBSCRIBE EDISTA "your_full_name" to LISTSERV@USACHVM1.BITNET. Messages to the list can be sent via bitnet: EDISTA@ USACHVM1.BITNET.

\section{Electronic journals and newsletters}

There are some electronic journals and newsletters that are of particular interest to distance educators.

- DISTED. The Online Journal of Distance Education and Communication from the University of Alaska. Articles focus on four content areas: distance education, distance communication, telecommunications in education, and cross-cultural communication. Subscribe: send the message SUB DISTED your_full_name to LISTSERV@UWAVM. A subscription will provide references to articles that 
can be retrieved directly from the listserv or via anonymous ftp.

- JTE-L. Journal of Technology Education. Produced by the Technology Education Program at Virginia Polytechnic Institute and State University and featuring peer-reviewed articles on technology in education. Subscribe: send the message SUBSCRIBE JTE-L First Name Last Name to LISTSERV@VTVM1.CC.VT.EDU or LISTSERV@VTVM1 (bitnet). A list of all files can be obtained by sending the message INDEX JTE-L to LISTSERV@VTVM1.

- JOE. Joumal of Extension published by the University of Wisconsin. Refereed publication of the Cooperative Extension System, covers extension and adult education issues. Sub scribe: send the message: subscribe joe to almanac@joe.uwex.edu. Full-text articles are available directly from the listserv or via anonymous ftp.

- IPCT. Interpersonal Computing and Technology: An Electronic Journal for the 21st Century. Published by the Center for Teaching and Technology, Academic Computing Center at Georgetown University, the journal includes peer-reviewed articles on the use of computers and other electronic communication systems used in higher education. Subscribe: send the message: SUBSCRIBE IPCT-J YOURFIRSTNAME YOURLASTNAME to LISTSERV@GUVM.GEORGETOWN.EDU or LISTSERV@GUVM.

\section{Databases}

There are some special databases of interest in $\mathrm{DE}$.

- ERIC provides a rich repository of educationally related papers, studies, reports and information; has abundant DE materials; and can be reached through Syracuse University, the University of Maryland, Auburn University and other libraries. The Washington and Lee Law Library offers an easy-to-use interface (telnet to liberty.uc.wlu.edu and login as lawlib).

- The International Centre for Distance Learning (ICDL) based at the British Open University, has a large online database on $\mathrm{DE}$. This database has been developed with funding from the British government's Overseas Development Administration to provide an information service to the Commonwealth of Learning (based in Canada), an organization created by Commonwealth Heads of Government to expand opportunities for students in Commonwealth countries through DE. There are three sections in the database: courses, institutions, and literature. There are costs associated with the use of this database; it can be accessed from the Internet using telnet: telnet acsvax.open.ac.uk, login: icdl.

- The scholarly papers archive of the joint AARE/NZARE Education Research Conference which was held at Deakin University in Geelong, Australia, are available via ftp: host: sol.deakin.edu.au; directory: aare; login: anonymous; password: your e-mail address.

There is a readme file which outlines information about the papers and the file that contains abstracts of all papers found in the same / aare directory as the file "readme".

- The Cleveland Free-net (telnet to freenetin-a.cwru.edu and register as a visitor unless you have an account). Archives the papers and scholarly list transcripts from what is known as the Bangkok Distance Learning Conference (The International Conference on Distance Education, November 6-8, 1992, Sukhothai Thammathirat Open University, Bangkok, Thailand). This conference generated a great deal of interest on the nets as it was taking place. The archives can be found in the Usenet news section of the Free-net. The Usenet can be accessed from The Teleport section from the main directory. Usenet DE archival files:

\section{alt.education.bangkok \\ alt.education.bangkok.cmc \\ alt.education.bangkok.databases \\ alt.education.bangkok.planning \\ alt.education.bangkok.research \\ alt.education.bangkok.student \\ alt.education.bangkok.theory \\ alt.education.distance}

In addition, in alt.education.distance some of the topics currently include the National Instructional Satellite Service, the Davenport Media Literacy Program, distance learning programs in physics, GED materials, computer mediated distance learning, the University of Phoenix distance learning degree programs, copyrights and distance learning, and more. As with most archives and usenet lists, the material changes day to day.

\section{Other resources}

- The National Project for Computer-based Distance Education at Miami Dade Community College.

(Internet cont. on page 258) 


\section{Letters}

\section{Food in the library}

To the Editor:

I read with interest the article entitled "No food, no drink, no noise" (February 1994) and I was amused by the author's innovative signs such as "Ravenous Roaches Ravage Rootbeer and Rare Books."

Two years ago our library ciropped its "no drink" policy and began allowing drinks in any kind of covered container. We also eased our "no food" policy, prohibiting only messy, smelly foods such as pizzas or hamburgers and fries, etc. We have even gone as far as to establish an annual Christmas party in the library. The library provides the drinks, cookies, snacks, and loud Christmas music. The students LOVE it!

In two years I have yet to see a roach in our library. In fact, I have detected no major spills, wet books, water rings, or any of the other nightmares librarians have about allowing food and clrink in the library.

In my judgment, this is a customer service issue. I want to do everything reasonable to make our students feel good about libraries. Allowing food and drinks has been a reasonable concession and, I believe, it has had very positive repercussions._Dennis Ingolfsland, Bryan College

\section{More women's studies resources on the Net...}

To the Editor:

I am writing in response to Mary Glazier's article, "Internet resources for women's studies" (March 1994). I have been doing research on women's studies and the Internet and was very glad to see such attention given to women's studies.

However, I would like to call your attention to an oversight in that article: since there are no databases/CD-ROMs dedicated to women's studies, and others may include only some women's studies journals, a database which includes almost all (over 80 ) such journals is CARL UnCover. CARL UnCover is available through the Internet by telnetting to uncover.carl.org. Also, a list I compiled of the women's studies-related journals on CARL UnCover and some search tips are available on the University of Maryland gopher. Telnet to inform.umd.edu, then choose 4. Educational Resources, 17. Women's studies, 11. Resources, then 6. Using CARL UnCover.

Access to women's studies information is a major concern of all librarians because women's studies has been integrated into all subjects, in particular literature, sociology, and psychology. CARL UnCover is a great resource for women's studies information.-Jill Morrissey, University of Connecticut

\section{... and another}

To the Editor:

As a women's studies librarian, I was very pleased to see Mary Glazier's article in the March 1994 issue of CERL News.

I must point out, however, that Glazier makes an unfortunate omission by neglecting to mention the Schlesinger Library on the History of Women in America in her section on OPACs.

The Schlesinger Library is one of the largest and best-known women's history libraries in the world. All of our holdings, including 50,000 books and 2,000 manuscript collections, are listed on Harvard's online catalog, HOLLIS. To access HOLLIS, teinet to HOLLIS.HARVARD.EDU. Press return for vt 100 terminals, or enter in another type. Select HOLLIS from the next ment. Our holdings are included in the HU database.-Wendy Thomas, Radcliffe College

\section{(Internet cont. from page 257)}

- The National Distance Learning Center Clearinghouse at Owenshoro Community College in Kentucky.

- The Centre for Distance Education at Athabasca University is creating a database of e-mail addresses of adult and distance education researchers in an effort to provide information and connections.

- At the University of Washington, IBM and the university maintain a Bulletin Board Service for educators which contains a conference on DE. It may be reached by telnet to isaac.engr.washington.edu or 128.95.32.61. This service requires registration. 